\title{
Beta Adrenergic Receptors in Lymphocytes and Granulocytes from Patients with Cystic Fibrosis
}

\author{
Pamela B. Davis, Lynda Dieckman, Thomas F. Boat, Robert C. Stern, and \\ Carl F. Doershuk, Departments of Medicine and Pediatrics, Case Western \\ Reserve University School of Medicine, Cleveland, Ohio 44106
}

\begin{abstract}
A B S T R A C T Intact lymphocytes from patients with cystic fibrosis $(\mathrm{CF})$ produce significantly $(P<0.001)$ less adenosine $3^{\prime}: 5^{\prime}$ cyclic monophosphate (cAMP) than normal lymphocytes in response to isoproterenol $\left(10^{-8}\right.$ $\left.10^{-4} \mathrm{M}\right)$, although the basal cAMP content and the response to prostaglandin $E_{1}$ are normal. Obligate heterozygotes for $C F$ have significantly $(P<0.005)$ reduced cAMP response to isoproterenol as well, suggesting a genetic component in the beta adrenergic deficiency in $\mathrm{CF}$. The number of beta adrenergic receptors, as determined by equilibrium binding of $\left[{ }^{3} \mathrm{H}\right]$ dihydroalprenolol to lymphocyte particulates, is the same in normal lymphocytes $(969 \pm 165$ receptors/ cell) and lymphocytes from patients with CF $(1,333 \pm 263$ receptors/cell). Binding properties of the receptor for both antagonist and agonist, as assessed by $K_{\mathrm{D}}$ for dihydroalprenolol and $K_{\mathrm{i}}$ for $(-)$-isoproterenol, are also normal in the CF lymphocytes. Similarly, in granulocytes from patients with $\mathrm{CF}$, the cAMP response to isoproterenol $\left(10^{-8}-10^{-4} \mathrm{M}\right)$ is significantly reduced compared with healthy controls $(P<0.03)$, as is the response of granulocytes from obligate heterozygotes $(P<0.05)$. Again, the basal cAMP levels and the response to prostaglandin $E_{1}$ are normal. The number of beta adrenergic receptors, as determined by equilibrium binding of $\left[{ }^{3} \mathrm{H}\right]$ dihydroalprenolol to granulocyte particulates, was the same in normal (1,462 \pm 249 receptors/cell) and CF $(1,621 \pm 221$ receptors/cell) preparations. Binding properties of the receptor for both agonist and antagonist, as assessed by $K_{\mathrm{D}}$ for dihydroalprenolol and $K_{\mathrm{i}}$ for isoproterenol, are normal in CF granulocyte particulates. The lymphocyte and granulocyte beta adrenergic defect in CF cannot be explained by abnormalities of the beta ad-
\end{abstract}

\footnotetext{
Parts of this study were presented at the meeting of the Central Society for Clinical Investigation, Chicago, IL, 4 November 1982.

Received for publication 14 September 1982 and in revised form 4 February 1983.
}

renergic receptor or of adenylate cyclase itself. Receptor-cyclase coupling is the most likely site of the heritable beta adrenergic defect in CF.

\section{INTRODUCTION}

Reduced beta adrenergic responses have been demonstrated in lymphocytes, granulocytes, and the cardiovascular system of patients with cystic fibrosis $(\mathrm{CF})^{1}$ (1-5). In leukocytes, the defect appears to be present in attenuated form in obligate heterozygotes for $\mathrm{CF}$, suggesting that it is inherited and not acquired as a result of disease $(1,4)$. This suggestion is further supported by the lack of relation of the CF beta adrenergic abnormality to major organ involvement or to severity of pulmonary disease (1-4). The biochemical basis for this abnormality is uncertain. The same cells that fail to produce normal amounts of adenosine $3^{\prime}: 5^{\prime}$ cyclic monophosphate (cAMP) in response to beta adrenergic agonists respond normally to prostaglandin $\mathrm{E}_{1}\left(\mathrm{PGE}_{1}\right)$ $(1,2,4,5)$, suggesting that the capacity of adenylate cyclase to respond to hormonal stimuli is intact. In fact, adenylate cyclase activity in lymphocyte and granulocyte particulates is normal in its basal state and in response to $5^{\prime}$-guanylyl imidodiphosphate $(\mathrm{GppNHp}), \mathrm{PGE}_{1}$, and fluoride, but deficient in response to isoproterenol (2). This places the abnormality at the level of the beta adrenergic receptor or the receptor-cyclase coupling. Galant et al. (4) reported that in whole granulocytes from patients with CF the number of beta adrenergic receptors is reduced. However, the parents of CF patients, who also had reduced cAMP response to isoproterenol, had normal beta receptor number. Because lymphocytes and granulocytes may differ with respect to beta adrenergic re-

\footnotetext{
${ }^{1}$ Abbreviations used in this paper: cAMP, adenosine $3^{\prime}: 5^{\prime}$ cyclic monophosphate; CF, cystic fibrosis; GppNHp, 5'-guanylyl imidodiphosphate; $\left[{ }^{3} \mathrm{H}\right] \mathrm{DHA},\left[{ }^{3} \mathrm{H}\right]$ dihydroalprenolol; $\mathrm{PGE}_{1}$, prostaglandin $\mathrm{E}_{1}$.
} 
ceptor responses to pharmacologic agents $(6,7)$ and disease (8), we examined the beta adrenergic receptor in lymphocytes as well as granulocytes from patients with $\mathbf{C F}$.

\section{METHODS}

Subjects. Patients were diagnosed as having CF based on sweat chloride $>70 \mathrm{meq} / \mathrm{liter}$ and the presence of either chronic pulmonary disease of appropriate character, or pancreatic insufficiency, or both. All were 13 to $27 \mathrm{yr}$ of age, had clinical score $(9)>69$, no acute illness, and had not received treatment with beta adrenergic agents or theophyllines during the previous month. They had been treated with pancreatic enzymes, vitamins, oral or inhaled antibiotics, and, in one case, cimetidine. Obligate heterozygotes for $\mathrm{CF}$ were parents of a child meeting the above criteria for diagnosis of $\mathrm{CF}$, denied medical illness or medication usage, and were age 27-45 yr. Healthy controls aged 19-35 yr were recruited by advertisement and admitted no medication usage and no medical illnesses. The study was approved by the Institutional Review Board, and all subjects granted their informed consent.

Cell preparation. Whole blood was mixed with acid citrate dextrose anticoagulant $(1.5 \mathrm{ml} / 10 \mathrm{ml}$ blood) and centrifuged for $20 \mathrm{~min}$ at $180 \mathrm{~g}$. The layer of platelet-rich plasma was removed, and the lower layer restored to its original volume with normal saline. Dextran was added to final concentration $0.8 \%$ and the mixture allowed to sediment at room temperature for 30-60 $\mathrm{min}$. The leukocyte-rich saline was layered onto a cushion of Histopaque (Sigma Chemical Co., St. Louis, MO) and centrifuged for $30 \mathrm{~min}$ at room temperature at $400 \mathrm{~g}$ as described by Boyum (10). The lymphocytes were recovered at the interphase and washed three times with normal saline. Granulocytes were recovered in the pellet, freed of contaminating erythrocytes by hypotonic lysis, and washed three times with normal saline.

Lymphocyte particulates. Washed lymphocytes were resuspended in distilled water and allowed to sit on ice at least $10 \mathrm{~min}$. They were then lysed by Polytron action $(15 \mathrm{~s}$ at setting of 8 ), and the resulting suspension centrifuged at $4^{\circ} \mathrm{C}$ for $10 \mathrm{~min}$ at $39,000 \mathrm{~g}$. The pellet was washed in buffer containing $50 \mathrm{mM}$ Tris, $\mathrm{pH} 7.4$, and $10 \mathrm{mM} \mathrm{MgCl}$, and finally resuspended in this buffer with a motor-driven Teflon pestle for use in the receptor-binding assays. This method is a modification of that of Aarons et al. (11).

Granulocyte particulates. Washed granulocytes were resuspended in buffer containing $50 \mathrm{mM}$ Tris, $\mathrm{pH} 7.4$ and 10 $\mathrm{mM} \mathrm{MgCl}{ }_{2}$, and lysed by Polytron action (15 s at setting of 8.). The lysate was centrifuged at $4^{\circ} \mathrm{C}$ for $10 \mathrm{~min}$ at 39,000 $g$, washed once, and resuspended in this buffer with a motordriven Teflon pestle.

Intact cell studies. Whole lymphocytes or granulocytes were suspended in normal saline containing $50 \mathrm{mM}$ Tris, $\mathrm{pH}$ 7.4 , and $8 \mathrm{mM}$ theophylline and incubated for $5 \mathrm{~min}$ at room temperature. The cell suspension $(70 \mu \mathrm{l})$ was then added to tubes containing either $\mathrm{PGE}_{1}\left(10^{-8}-10^{-5} \mathrm{M}\right)$, isoproterenol $\left(10^{-8}-10^{-4} \mathrm{M}\right)$, isoproterenol and propranolol, or buffer (total volume, $100 \mu \mathrm{l}$ ), and incubated $5 \mathrm{~min}$ at $37^{\circ} \mathrm{C}$. The reaction was terminated by boiling for $2 \mathrm{~min}$. The samples were diluted with $400 \mu \mathrm{l}$ distilled water and frozen for later assay in duplicate for cAMP by the method of Brown et al. (12).

Beta adrenergic receptor assays. Binding of $\left[{ }^{3} \mathrm{H}\right]$ dihydroalprenolol $\left.\left({ }^{3} \mathrm{H}\right] \mathrm{DHA}\right)$ to lymphocyte or granulocyte particulates was conducted at $37^{\circ} \mathrm{C}$ in buffer containing $50 \mathrm{mM}$ Tris, $\mathrm{pH} 7.4$ and $10 \mathrm{mM} \mathrm{MgCl}$ in total volume $500 \mu \mathrm{l}$ as described by Williams et al. (13). Nonspecific binding was taken as that not displaced by $10^{-5} \mathrm{M}$ DL-propranolol, and ranged from $20-50 \%$ of total binding for lymphocyte particulates and $30-60 \%$ for granulocyte particulates. At the end of the incubation period, the mixture was diluted with $3 \mathrm{ml}$ cold buffer, and bound ligand was separated from free by rapid $(<15 \mathrm{~s})$ filtration onto Whatman GF/C filters (Whatman, Inc., Clifton, $\mathrm{NJ}$ ) under vacuum, followed by washing of the filters with $20 \mathrm{ml}$ ice-cold buffer. Filters were then dried and counted in a Searle liquid scintillation counter with efficiency for ${ }^{3} \mathrm{H}$ of $40-44 \%$ (Searle Radiographics, Inc., Des Plaines, IL). Specific binding increased linearly with added protein over the range used in these assays (50-300 $\mu \mathrm{g}$ for lymphocytes, 50-500 $\mu \mathrm{g}$ for granulocytes).

For equilibrium binding studies, $\left[{ }^{3} \mathrm{H}\right] \mathrm{DHA}$ (at least five concentrations, 0.5-5 $\mathrm{nM}$ ) was incubated for $20 \mathrm{~min}$ with the particulates. $K_{D}$, the binding constant for $\left[{ }^{3} \mathrm{H}\right] \mathrm{DHA}$ and $B_{\max }$, the theoretical maximum binding, were calculated by Scatchard analysis (14).

For studies of displacement of binding by adrenergic agents, $4 \mathrm{nM}\left[{ }^{3} \mathrm{H}\right] \mathrm{DHA}$ was used. Solutions of agonists were prepared in buffer containing ascorbic acid $(1 \mathrm{mM})$, which by itself had no effect on ligand binding. $K_{\mathrm{i}}$, the dissociation constant for each agonist, was calculated by the method of Cheng and Prusoff (15): $K_{\mathrm{i}}=\mathrm{IC}_{50} / 1+[\mathrm{DHA}] / K_{\mathrm{D}}$, where the $\mathrm{IC}_{50}$ is the concentration of agonist required to cause $50 \%$ inhibition of specific binding, and [DHA] is the concentration of $\left[{ }^{3} \mathrm{H}\right] \mathrm{DHA}$ used in the assay (in this case, $4 \mathrm{nM}$ ).

Enzyme assays. Adenylate cyclase was assayed as described previously (2); 5'nucleotidase was assayed by two methods, one as described by Dixon and Purdom (16) and one as described by Arkesteijn (17) with reagents provided in kit form by Sigma Chemical Co. Protein was determined by the Bio-Rad procedure (18) and cell counts were performed manually using a hemocytometer.

Statistical analyses. Student's $t$ test was used for comparison of means. Lines were fitted to the points obtained for Scatchard analysis by the method of least squares. Comparison of curves was performed by Anova with multiple samples correction applied.

Materials. PGE $_{1}$ was purchased from the Upjohn Co., Kalamazoo, MI. $\left[{ }^{3} \mathrm{H}\right] \mathrm{cAMP}$ and $\left[{ }^{3} \mathrm{H}\right] \mathrm{DHA}$ were purchased from Amersham Corp., Arlington Heights, IL. Theophylline, $(+)$ - and (-)-isoproterenol, GppNHp, propranolol, and other laboratory chemicals were purchased from Sigma Chemical Co.

\section{RESULTS}

Intact lymphocyte studies. Basal levels of cAMP were: $26.2 \pm 8.2 \mathrm{pmol} / 10^{6}$ normal cells, $17 \pm 10 \mathrm{pmol} /$ $10^{6} \mathrm{CF}$ heterozygote cells, and $28.7 \pm 9.5 \mathrm{pmol} / 10^{6} \mathrm{CF}$ cells. Although the $\mathrm{CF}$ heterozygotes are somewhat older than the other two groups, they are shown on the same graph because in the age range of all these subjects (13-45 yr), leukocyte cAMP response to isoproterenol (unlike beta adrenergic receptor number) does not vary with age $(1,4)$. The cAMP response to isoproterenol is significantly reduced in lymphocytes from CF patients at all concentrations of isoproterenol tested (Fig. 1). In lymphocytes from obligate heterozygotes for CF, the cAMP response to isoproterenol was intermediate between the normal and the CF cells' 


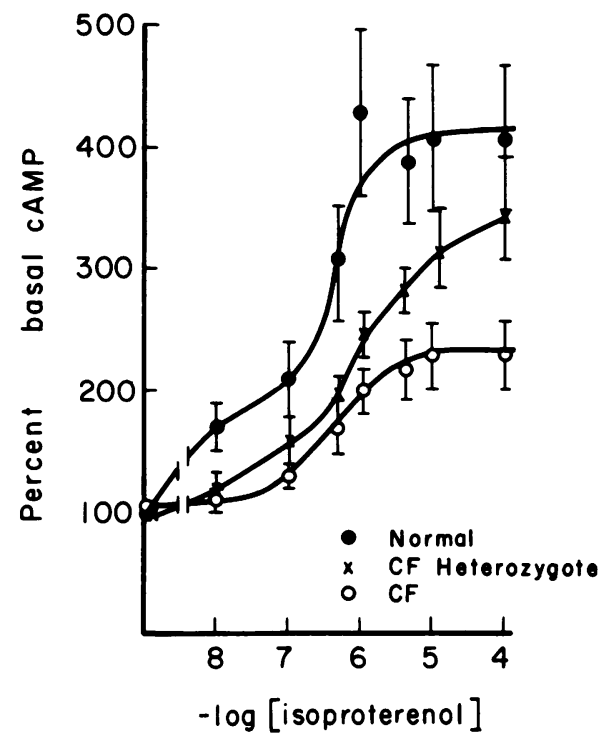

Figure 1 Stimulation by (-)-isoproterenol of cAMP levels in intact lymphocytes from nine normal subjects, eight obligate heterozygotes for CF, and eight patients with CF. Methods are described in the text. Results are expressed as a percentage of the cAMP accumulation that occurred in the absence of agonist. Points indicate mean values and bars, SEM. At each concentration tested, CF cells produced significantly less cAMP than normal cells $(P<0.01, t$ test $)$. The cells from $C F$ heterozygotes produced significantly less cAMP than normal cells at isoproterenol concentrations of $10^{-8}, 10^{-7}, 5 \times 10^{-7}$ and $5 \times 10^{-6} \mathrm{M}(P<0.05, t$ test $)$. Comparison of the curves by Anova indicates that a significant amount of the variance of the samples is accounted for by the CF genotype $(F=32.2, P<0.001$ for $C F$ and normal subjects; $F=9.9, P=0.003$ for $C F$ heterozygote and normal subjects; $F=16.5, P<0.001$ for $C F$ and $C F$ heterozygote subjects; $F=19.9, P<0.001$ for all three genotypes).

responses, and, when the curve was analyzed by Anova, was significantly different from both $(P<0.003)$. The concentration of isoproterenol required to elicit a half-maximal increase in cAMP concentration $\left(\mathrm{EC}_{50}\right.$ for isoproterenol) was calculated for each subject, and averaged $2.64 \pm 1.7 \times 10^{-7} \mathrm{M}$ for the normal lymphocytes and $8.38 \pm 1.5 \times 10^{-7} \mathrm{M}$ for $\mathrm{CF}$ lymphocytes $(P$ $<0.01)$. The value for heterozygotes was intermediate, $6.43 \pm 3.1 \times 10^{-7} \mathrm{M}$. Addition of propranolol $\left(2 \times 10^{-5}\right.$ M) to samples containing isoproterenol $\left(10^{-5} \mathrm{M}\right)$ resulted in $85 \pm 5 \%$ inhibition of cAMP accumulation in all samples. The cAMP response to $\mathrm{PGE}_{1}$ does not differ significantly among $C F$ patients, obligate heterozygotes for CF, and normal controls (Fig. 2).

Intact granulocyte studies. Basal levels of cAMP were: $2.1 \pm 0.6 \mathrm{pmol} / 10^{6}$ normal cells, $1.5 \pm 0.5 \mathrm{pmol} /$ $10^{6} \mathrm{CF}$ heterozygote cells, and $1.9 \pm 0.7 \mathrm{pmol} / 10^{6} \mathrm{CF}$ cells. Granulocyte cAMP response to isoproterenol does not vary with age over the range of ages of the present subjects (1). The cAMP response to isoproterenol in granulocytes from CF patients differs significantly from that of cells from healthy controls $(P=0.03$ by Anova), but not from that of obligate heterozygotes for CF (Fig. 3). The response of granulocytes from obligate heterozygotes for $\mathrm{CF}$ to isoproterenol differs significantly from that of control subjects $(P=0.05$ by Anova). The concentration of isoproterenol required to elicit a half-maximal increase in cAMP concentration $\left(\mathrm{EC}_{50}\right.$ for isoproterenol) was calculated for each subject, and averaged $1.0 \pm 1.0 \mu \mathrm{M}$ for the normal granulocytes, $1.7 \pm 0.7 \mu \mathrm{M}$ CF cells, and $2.7 \pm 1.0 \mu \mathrm{M}$ for cells from heterozygotes. Propranolol $\left(2 \times 10^{-5} \mathrm{M}\right)$ inhibited the response to isoproterenol $\left(10^{-5} \mathrm{M}\right)$ by $>80 \%$ in all samples. The cAMP response to $\mathrm{PGE}_{1}$ does not differ significantly among CF patients, obligate heterozygotes for CF, and normal controls (Fig. 4).

Lymphocyte receptor binding studies. Specific binding of $\left[{ }^{3} \mathrm{H}\right] \mathrm{DHA}$ to normal lymphocyte particulates was rapid $\left(t_{1 / 2}=1.75 \mathrm{~min}\right.$, with equilibrium achieved at $20 \mathrm{~min})$, and reversible $\left(t_{1 / 2}=1.25 \mathrm{~min}\right)$. Kinetic analysis was performed using the following four equations: (a) $k_{2} t=\ln \left(\mathrm{b} / \mathrm{b}_{\mathrm{eq}}\right)$, where $k_{2}$ is the

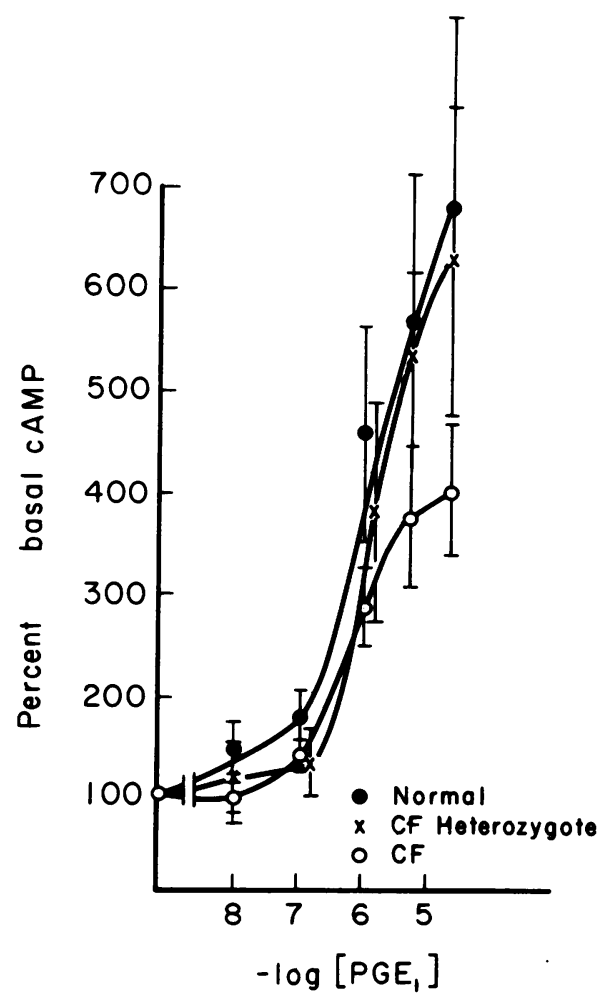

Figure 2 Stimulation by $\mathrm{PGE}_{1}$ of cAMP levels in intact lymphocytes. Subjects and symbols are described in the legend to Fig. 1. No significant difference among the groups is demonstrated. 


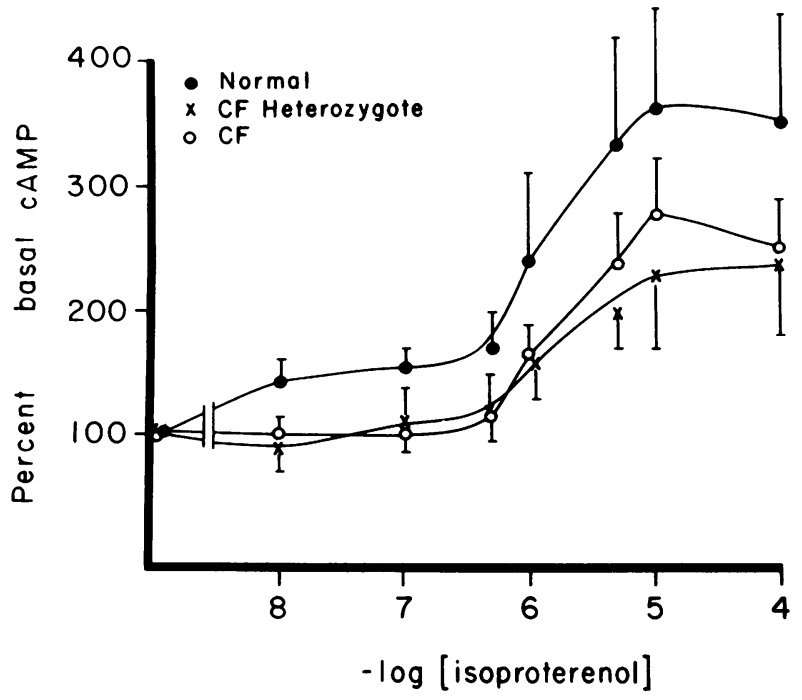

Figure 3 Stimulation by (-)-isoproterenol of cAMP levels in intact granulocytes from nine normal subjects, seven obligate heterozygotes for CF, and nine patients with CF. Symbols are as for Fig. 1. At isoproterenol concentrations from $10^{-8}$ to $10^{-6} \mathrm{M}, \mathrm{CF}$ cells produced significantly less cAMP than normal cells $(P<0.05, t$ test $)$. The cells from $C F$ heterozygotes produced significantly less cAMP than normal cells at isoproterenol concentrations of $10^{-8}$ and $10^{-7} \mathrm{M}$ $(P<0.05, t$ test). Comparison of the curves by Anova indicates that a significant amount of the variance of the samples is accounted for by the CF genotype $(F=4.64, P=0.03$ for $C F$ and normal subjects; $F=3.9, P=0.05$ for $C F$ heterozygote and normal subjects). CF and CF heterozygote cells do not differ significantly.

reverse rate constant, $b_{\text {eq }}$ is the amount of $\left[{ }^{3} \mathrm{H}\right] \mathrm{DHA}$ specifically bound at equilibrium and $b$ is the amount of $\left[{ }^{3} \mathrm{H}\right] \mathrm{DHA}$ bound at time $t$. (b) $k_{\mathrm{obs}} t=\ln \left(\mathrm{b}_{\mathrm{eq}} / \mathrm{b}_{\mathrm{eq}}\right.$ $-b)$, where $k_{\text {obs }}$ is the apparent forward rate constant. (c) $k_{1}=k_{\text {obs }}-k_{2} /[\mathrm{DHA}]$, where $k_{1}$ is the forward rate constant. (d) $K_{\mathrm{D}}=k_{2} / k_{1} . K_{\mathrm{D}}$ calculated in this way was $1.4 \mathrm{nM}$, which approximates the value derived from Scatchard analysis of equilibrium binding data $(2.3 \pm 0.8 \mathrm{nM})$.

Scatchard analysis using the equation $B / F=-K_{D}{ }^{-1}$ $\left(B_{\max }-B\right)$, where $B$ is the amount of $\left[{ }^{3} \mathrm{H}\right] \mathrm{DHA}$ specifically bound at free ligand concentration $F(14)$, was used to determine $K_{D}$ and $B_{\max }$, a measure of receptor number. Scatchard plots gave straight lines in each case $(r>0.84, P<0.05)$ (Fig. 5). Because of suggestions that a high-capacity, low-affinity $\left[{ }^{3} \mathrm{H}\right] \mathrm{DHA}$ binding site might be occupied in lymphocytes at ligand concentrations as low as 4-5 $\mathrm{nM}(6)$, the data were recalculated using only points obtained at concentrations of ligand $<3 \mathrm{nM}$, but no change in either $K_{D}$ or $B_{\max }$ resulted. In addition, binding was stereospecific at $\left[{ }^{3} \mathrm{H}\right] \mathrm{DHA}$ concentration of $4 \mathrm{nM}$ (Table I, Fig. 6).

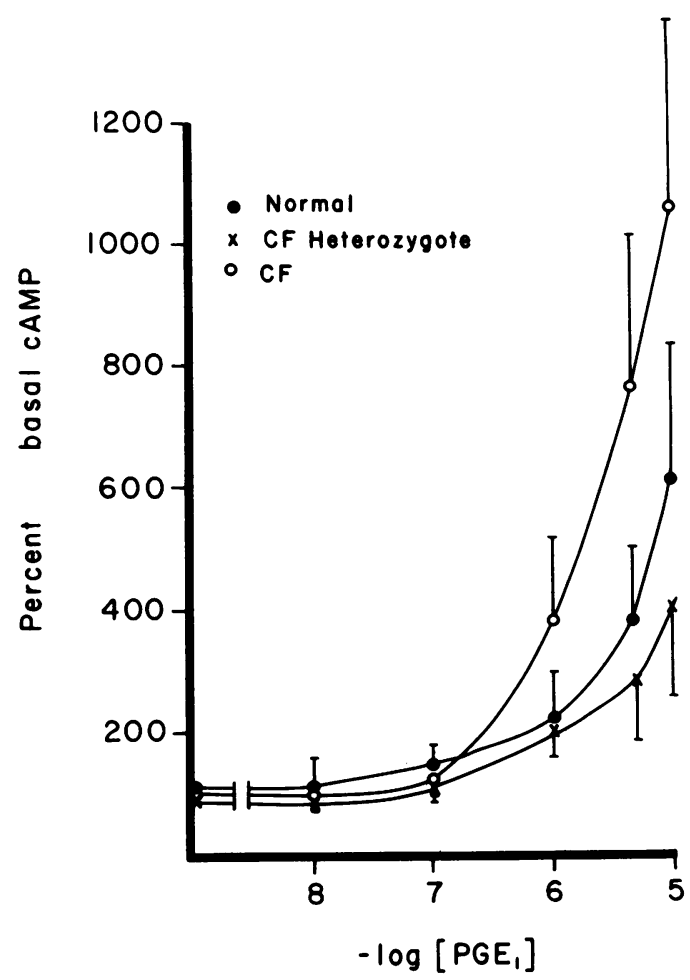

Figure 4 Stimulation by $\mathrm{PGE}_{1}$ of cAMP levels in intact granulocytes. Subjects are described in the legend to Fig. 2 and symbols, in the legend to Fig. 1. CF and CF heterozygote subjects do not differ from the controls.

The receptor number was expressed as the number of receptors recovered in the particulate fraction per cell used to prepare that fraction. For two healthy normal subjects, the number of receptors was determined on three occasions at least $1 \mathrm{wk}$ apart. The coefficients of variation were 10 and $19 \%$, comparable to other figures in the literature for intrasubject variability of lymphocyte beta adrenergic receptor number in healthy outpatients eating ad lib. (19). One study

TABLE I

Binding Properties of the Lymphocyte Beta Adrenergic Receptor

\begin{tabular}{lcc}
\hline & Normal & CF \\
\hline$K_{\mathrm{D}}\left[{ }^{3} \mathrm{H}\right] \mathrm{DHA}$ & $2.3 \pm 0.8 \mathrm{nM}(9)$ & $2.5 \pm 0.4 \mathrm{nM}(9)$ \\
$K_{\mathrm{i}}(-)$-isoproterenol & $1.00 \pm 0.46 \mu \mathrm{M}(5)$ & $0.77 \pm 0.13 \mu \mathrm{M}(4)$ \\
$K_{\mathrm{i}(-) \text {-isoproterenol }}$ & & \\
$\quad+$ GppNHp & & \\
$\left(10^{-4} \mathrm{M}\right)$ & $6.5 \pm 2.6 \mu \mathrm{M}(5)$ & $10.0 \pm 2.2 \mu \mathrm{M}(4)$ \\
$K_{\mathrm{i}(+) \text {-isoproterenol }}$ & $224 \pm 103 \mu \mathrm{M}(5)$ & $139 \pm 74 \mu \mathrm{M}(4)$ \\
\hline
\end{tabular}

Values given are mean $\pm \mathrm{SEM}$, with number of subjects in parentheses. 


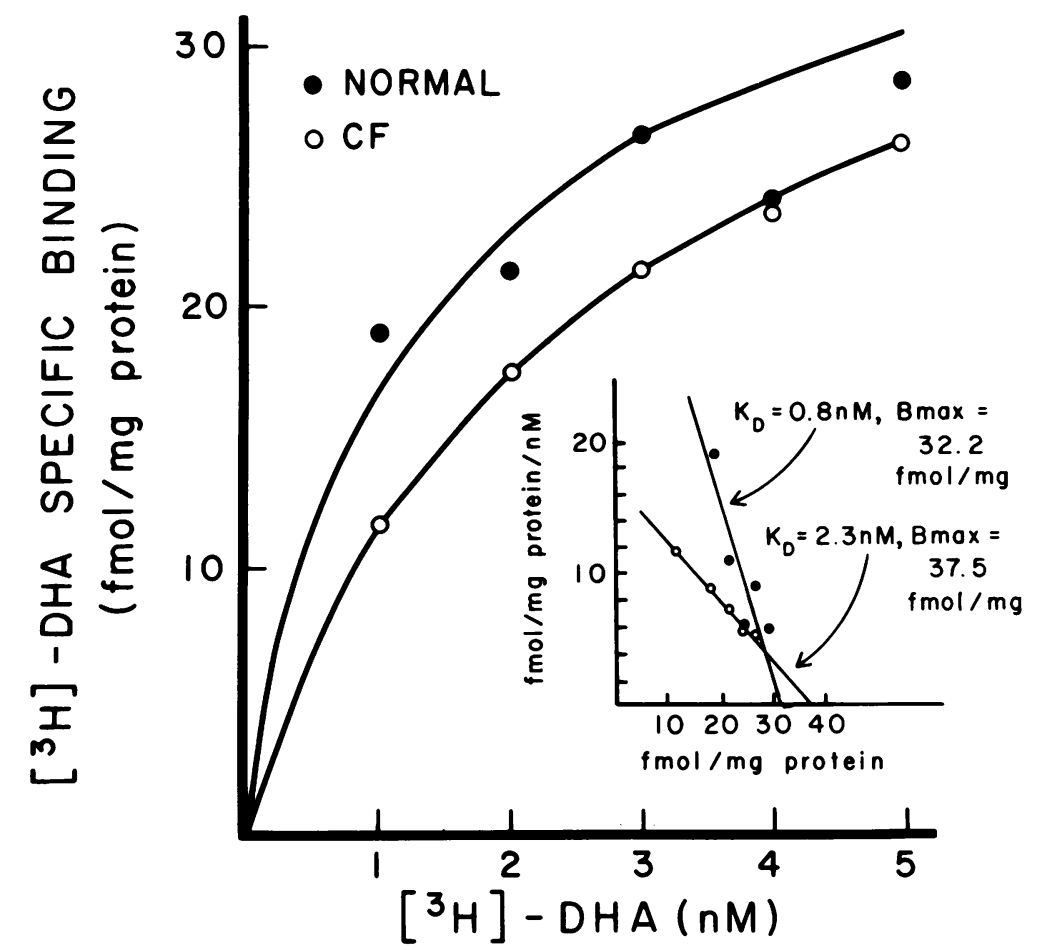

Figure 5 Sample equilibrium binding curves and Scatchard plots for $\left[{ }^{3} \mathrm{H}\right] \mathrm{DHA}$ binding to lymphocyte particulates from an 18-yr-old woman with CF and a 25-yr-old healthy man. Methods are described in the text.

(6) achieved a far better intersubject coefficient of variation (6\%). However, when we tried to duplicate these methods of membrane preparation, $>75 \%$ of the hormone-responsive adenylate cyclase activity and $65 \%$ of the 5'-nucleotidase activity were lost in the discarded pellet of a low-speed centrifugation step.

The binding of $\left[{ }^{3} \mathrm{H}\right] \mathrm{DHA}$ to both normal and $\mathrm{CF}$ lymphocyte particulates is stereoselective, with $K_{\mathrm{i}}$ for $(+)$-isoproterenol at least 100-fold greater than the $K_{i}$ for (-)-isoproterenol (Fig. 6, Table I). The order of potency of agonists corresponds to their relative potency in stimulating cAMP production, isoproterenol $>$ epinephrine $>$ norepinephrine $>$ phenylephrine. Therefore, binding is rapid, reversible, stereospecific, and has $K_{\mathrm{D}}$ calculated from kinetic studies comparable to $K_{\mathrm{D}}$ calculated from equilibrium binding studies, the properties expected for a beta adrenergic receptor. The number of receptor sites per lymphocyte as determined by Scatchard analysis did not differ between normal and CF cells, nine normal subjects having $969 \pm 165$ (SEM), and nine patients with CF, 1,333 \pm 263 binding sites/cell. The beta error for this determination is $17 \%$, in the direction of CF beta adrenergic receptor number greater than normal. The binding properties of these receptors, as assessed by $K_{\mathrm{D}}$ for $\left[{ }^{3} \mathrm{H}\right] \mathrm{DHA}$, and $K_{\mathrm{i}}$ for isoproterenol are also comparable

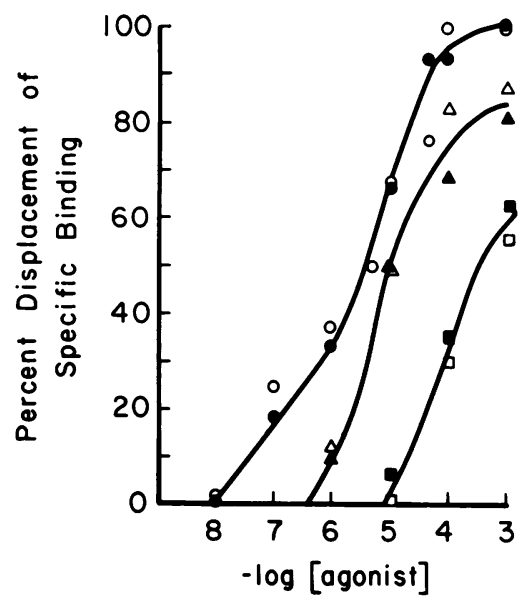

$$
\begin{array}{ccc}
\text { NORMAL } & \text { CF } \\
& \circ & (-) 1 S O \\
\Delta & \Delta & (-) 1 S O+\operatorname{GppNHp}\left(10^{-4} \mathrm{M}\right) \\
- & 0 & (+) 1 S O
\end{array}
$$

Figure 6 Displacement of specifically bound $\left[{ }^{3} \mathrm{H}\right] \mathrm{DHA}$ (4 nM) from lymphocyte particulates by agonists. Points represent means of determinations in five normal subjects and four patients with CF. Specific binding was defined as that displaced by $10^{-5} \mathrm{M}$ propranolol. Standard deviations for these points ranged from 2 to $13 \%$ of total specific binding. 
in normal and CF lymphocyte particulates (Table $\mathrm{I}$, Fig. 6). Beta error was $2.8 \%$ for $K_{\mathrm{D}}$ for $\left[{ }^{3} \mathrm{H}\right] \mathrm{DHA}$ and $7 \%$ for $K_{\mathrm{i}}$ for $(-)$-isoproterenol. Therefore, despite the small number of subjects, the chance that these two populations really differ with respect to these variables is $<7 \%$.

$K_{\mathrm{i}}$ for (-)-isoproterenol increases in the presence of GppNHp $\left(10^{-4} \mathrm{M}\right)$ in both normal and CF lymphocyte particulates (Fig. 6, Table I), but the magnitude of the increase cannot be emphasized because the particulates were not shown to be free of guanine nucleotides.

The number of receptors per cell was not significantly correlated with the percent increase in cAMP in response to isoproterenol or with the $\mathrm{EC}_{50}$ for isoproterenol for intact lymphocytes.

Granulocyte receptor binding studies. Nonspecific binding of $\left[{ }^{3} \mathrm{H}\right] \mathrm{DHA}$ to granulocyte particulates constituted as much as $60 \%$ of total binding at $5 \mathrm{nM}$ $\left[{ }^{3} \mathrm{H}\right] \mathrm{DHA}$. Addition of catechol or phentolamine or both to the assays had only a small effect $(\sim 10 \%)$ on nonspecific binding, so that these agents were not routinely used. Specific binding of $\left[{ }^{3} \mathrm{H}\right] \mathrm{DHA}$ to normal granulocyte particulates was rapid $\left(t_{1 / 2}=2.5 \mathrm{~min}\right.$, with equilibrium achieved at $20 \mathrm{~min}$ ), and reversible $\left(t_{1 / 2}\right.$ $=4.7 \mathrm{~min}) . K_{\mathrm{D}}$ calculated by kinetic analysis was 1.3 $\mathrm{nM}$, which approximates the value derived from Scatchard analysis of equilibrium binding data $(2.4 \pm 0.4 \mathrm{nM})$.

Scatchard plots gave straight lines in each case $(r$ $>0.80, P<0.05$ ) (Fig. 7). Again, the data were recalculated using only points obtained at concentrations of ligand $<3 \mathrm{nM}$. No change in either $K_{\mathrm{D}}$ or $\mathrm{B}_{\max }$ resulted in most subjects. In three subjects, $K_{\mathrm{D}}$ and $\mathrm{B}_{\max }$ both were reduced by recalculation, but substitution of these new values did not affect the group comparison of CF and normal subjects.

Receptor number was expressed as the number of receptors recovered in the particulate fraction per cell

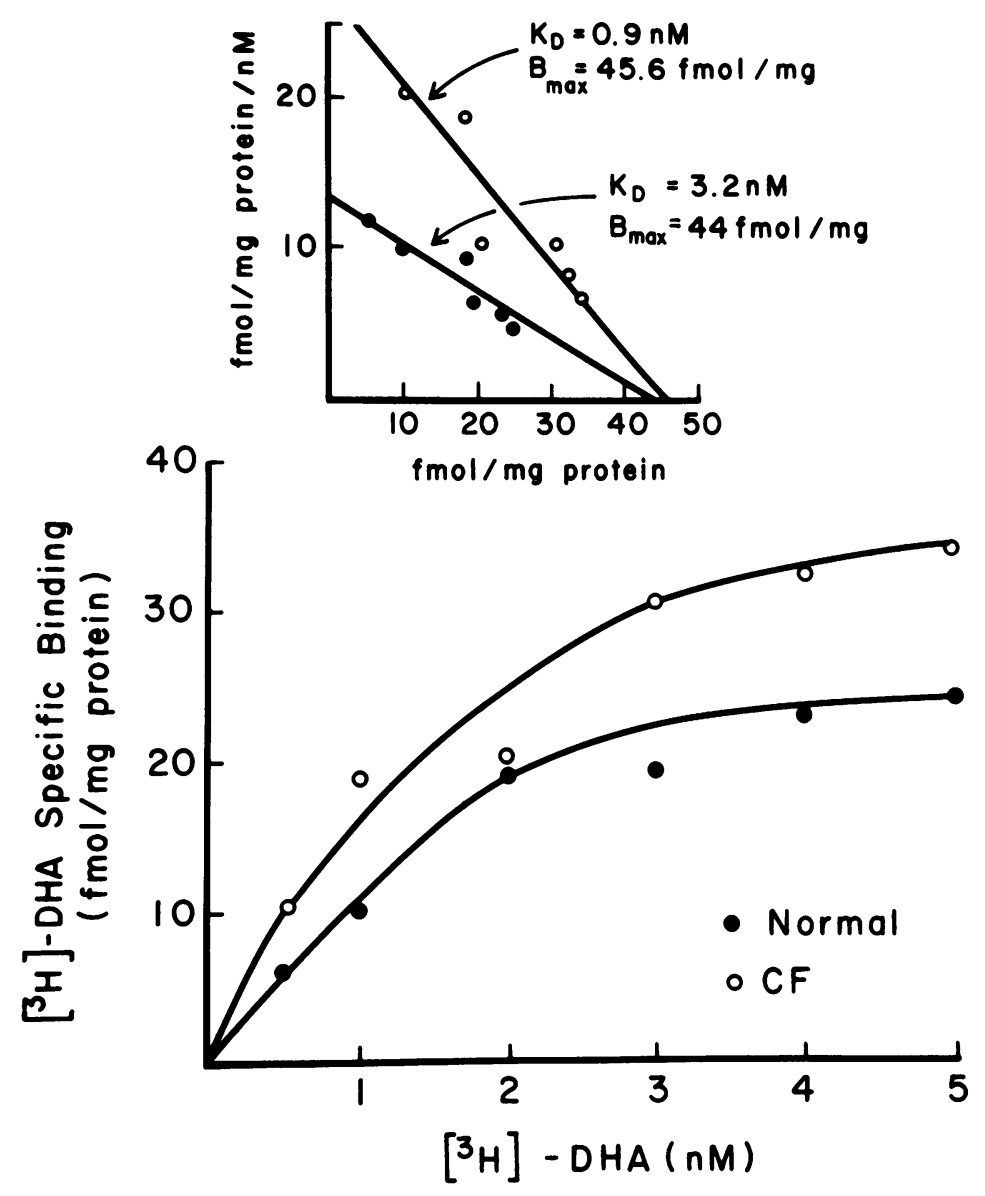

Figure 7 Sample equilibrium-binding curves and Scatchard plots for $\left[{ }^{3} \mathrm{H}\right] \mathrm{DHA}$ binding to granulocyte particulates from a 22 -yr-old man with CF and a 23 -yr-old healthy man. Methods are described in the text. 
used to prepare that fraction. The intrasubject coefficients of variation was 15 and $20 \%$ for granulocyte beta adrenergic receptor number in two healthy men, comparable to other figures in the literature (19). One study (6) achieved a far better intersubject coefficient of variation $(6 \%)$. However, when we tried to duplicate these methods of membrane preparation, over half the hormone-responsive adenylate cyclase and 5'-nucleotidase activity were lost in the discarded pellet of a low-speed centrifugation step.

The binding of $\left[{ }^{3} \mathrm{H}\right] \mathrm{DHA}$ to both normal and $\mathrm{CF}$ granulocyte particulates is stereoselective, with $K_{\mathrm{i}}$ for (+)-isoproterenol 40-350-fold greater than the $K_{\mathrm{i}}$ for (-)-isoproterenol (Fig. 8, Table II). The order of potency of agonists corresponds to their relative potency in stimulating cAMP production, isoproterenol $>$ epinephrine $>$ norepinephrine $>$ phenylephrine. Therefore, binding is rapid, reversible, stereospecific, and has $K_{\mathrm{D}}$ calculated from kinetic studies comparable to $K_{\mathrm{D}}$ calculated from equilibrium binding studies, the properties expected for a beta adrenergic receptor. The number of receptor sites per granulocyte as determined by Scatchard analysis did not differ between normal and CF cells, nine normal subjects having $1,462 \pm 249$ (SEM), and nine patients with CF, $1,621 \pm 221$ binding sites/cell, with beta error $7 \%$. The

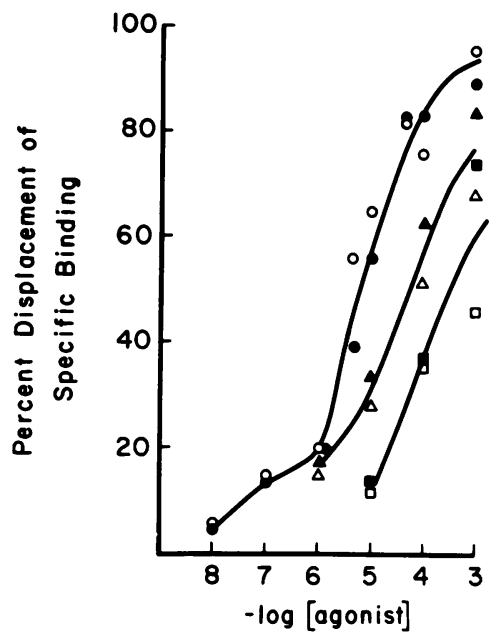

NORMAL $\quad$ CF

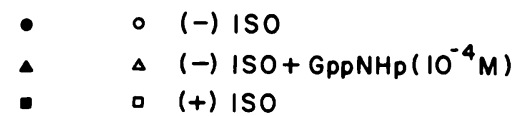

Figure 8 Displacement of specifically bound $\left[{ }^{3} \mathrm{H}\right] \mathrm{DHA}$ (4 $\mathrm{nM}$ ) from granulocyte particulates by agonists. Points represent means of determinations in six normal subjects and four patients with CF. Specific binding was defined as that displaced by $10^{-5} \mathrm{M}$ propranolol. Standard deviations for these points ranged from 4 to $15 \%$ of total specific binding.
TABLE II

Binding Properties of the Granulocyte Beta Adrenergic Receptor

\begin{tabular}{lrr}
\hline & \multicolumn{1}{c}{ Normal } & \multicolumn{1}{c}{$\mathrm{CF}$} \\
\hline$K_{\mathrm{D}}\left[{ }^{3} \mathrm{H}\right] \mathrm{DHA}$ & $2.4 \pm 0.4 \mathrm{nM}(8)$ & $2.7 \pm 0.6 \mathrm{nM}(9)$ \\
$K_{\mathrm{i}}(-)$-isoproterenol & $1.61 \pm 0.7 \mu \mathrm{M}(6)$ & $1.25 \pm 0.2 \mu \mathrm{M}(4)$ \\
$K_{\mathrm{i}}(-)$-isoproterenol & & \\
$\quad+$ GppNHp & & \\
$\left(10^{-4} \mathrm{M}\right)$ & $16.2 \pm 7.1 \mu \mathrm{M}(6)$ & $26.0 \pm 3.2 \mu \mathrm{M}(4)$ \\
$K_{\mathrm{i}}(+)$-isoproterenol & $68 \pm 101 \mu \mathrm{M}(6)$ & $423 \pm 252 \mu \mathrm{M}(4)$ \\
\hline
\end{tabular}

Values given are mean $\pm \mathrm{SEM}$, with number of subjects in parentheses.

binding properties of these receptors, as assessed by $K_{\mathrm{D}}$ for $\left[{ }^{3} \mathrm{H}\right] \mathrm{DHA}$, and $K_{\mathrm{i}}$ for isoproterenol are also comparable (with beta error $<10 \%$ ) in normal and CF granulocyte particulates (Table II, Fig. 8).

$K_{\mathrm{i}}$ for (-)-isoproterenol increases in the presence of GppNHp $\left(10^{-4} \mathrm{M}\right)$ in both normal and CF granulocyte particulates (Fig. 8, Table II), but the magnitude of the increase cannot be emphasized, because the preparation studied was not shown to be free of guanine nucleotides.

The number of receptors per cell was not significantly correlated with the percent increase in cAMP in response to isoproterenol or with the $\mathrm{EC}_{50}$ for isoproterenol for intact granulocytes.

\section{DISCUSSION}

Patients with CF and their parents have reduced lymphocyte and granulocyte cAMP responses to beta adrenergic stimulation (Figs. 1 and 3). The patients studied here were relatively well (score $>69$ ), had no acute illness, and had taken no beta adrenergic agonists or theophyllines for at least $30 \mathrm{~d}$. We have shown previously that patients with $\mathrm{CF}$ with and without pancreatic insufficiency have comparable degrees of beta adrenergic resistance in lymphocytes, granulocytes, and the cardiovascular system, so that it is unlikely that nutritional factors influenced our results $(2,3)$. Because there is no correlation between disease severity and the deficient leukocyte cAMP response to beta agents or cardiovascular beta adrenergic responses in vivo $(1,3,4)$, and because age-matched patients with bronchiectasis of non-CF etiology did not display the lymphocyte beta adrenergic abnormality (2), pulmonary disease per se probably does not produce this abnormality.

Even mildly affected patients with CF might be under some stress and therefore have circulating catecholamine excess and downregulated beta adrenergic receptors. However, adolescent and adult $\mathrm{CF}$ patients 
with clinical score $>70$, a group comparable to those who participated in the present study, had plasma norepinephrine concentrations that were normal in the resting state and in response to physiologic stimuli (standing and isometric exercise) (20). Therefore, the plasma catecholamine history of the CF patients studied here is likely to be comparable to that of the ambulatory healthy controls. Therefore, the beta adrenergic abnormality in CF probably cannot be attributed to endogenous circulating catecholamine excess leading to adrenergic downregulation.

Because the beta adrenergic defect in CF is observed in lymphocytes, granulocytes, and the cardiovascular system (1-5), it is unlikely to be an artifact of distribution of lymphocyte subpopulations, or of the presence of immature circulating granulocytes in CF patients.

In summary, patients with CF have a beta adrenergic defect, which does not appear to be an artifact of cell preparations or the result of pulmonary or pancreatic disease or medication usage. The presence of abnormal beta adrenergic responses in CF heterozygotes (Figs. 1 and 3) $(1,4)$ without overt disease also strongly suggests a heritable component. The biochemical basis of this abnormality is uncertain. The normal basal cAMP levels and normal response to $\mathrm{PGE}_{1}$ in $\mathrm{CF}$ cells (Figs. 2 and 4 ) exclude increased phosphodiesterase activity as a cause for reduced beta adrenergic response, and suggest that adenylate cyclase itself is intact. Indeed, in CF lymphocyte and granulocyte particulates, adenylate cyclase activity is normal in its basal activity, response to $\mathrm{GppNHp}$, and response to $\mathrm{PGE}_{1}(2)$. However, the response of adenylate cyclase to isoproterenol in the presence of $\mathrm{GppNHp}$ was markedly reduced. The persistence of the abnormality in broken cells, where substrate and cofactors are exogenously supplied, suggests that shortage of substrate or cofactors in vivo cannot explain the defect.

The present study indicates that the properties of the beta adrenergic receptor are normal in CF lymphocytes and granulocytes. Receptors are present in normal number in these cells, the $K_{\mathrm{D}}$ for the antagonist [ $\left.{ }^{3} \mathrm{H}\right] \mathrm{DHA}$ is normal, and the $K_{\mathrm{i}}$ for the agonist isoproterenol is normal and undergoes an appropriate shift in the presence of GppNHp. These findings differ from those of Galant et al. (4) who found that in the CF granulocyte, $K_{D}$ for $\left[{ }^{3} \mathrm{H}\right] \mathrm{DHA}$ is normal, but receptor number is reduced. There may be several reasons for the difference in our results. Our studies were done in a particulate fraction, and those of Galant et al. (4) were done on whole granulocytes. Breaking up the cells might alter the configuration of the receptors. However, the CF beta adrenergic defect persists in broken-cell preparations of both lymphocytes and granulocytes and adenylate cyclase response to iso- proterenol in particulates correlates well with wholecell cAMP response to isoproterenol (2). Therefore, this explanation seems unlikely. On the other hand, the intact granulocyte might be subject to artifacts such as uptake of the amine ligand into lysosomes down a pH gradient, as suggested by recent work by Styrt et al. (21), but this would not explain the reported stereospecificity of the system used by Galant et al. (4, 22). A more likely explanation for the difference between our results and Galant's is that the patient populations under study are different. We studied only patients with clinical score $>69$, whereas Galant et al. (4) included patients with more severe pulmonary disease, with scores as low as 35 .

Although Galant et al. (4) found reduced beta adrenergic receptor density in cells from CF homozygotes, they found that obligate heterozygotes for CF, who had reduced cAMP response to isoproterenol in granulocytes, had normal receptor density. In our study, in relatively well patients with CF, beta adrenergic receptor density is normal. Taken together, these findings are consistent with the hypothesis that the heritable aspect of the CF beta adrenergic defect is in the receptor-cyclase coupling, not receptor number. The moderately to severely ill patients with CF included in Galant et al.'s study population may have had, besides the heritable coupling defect, disease-related beta adrenergic receptor downregulation.

An isolated decrease in beta adrenergic receptor number would not explain the nature of the deficient cAMP response to isoproterenol in leukocytes from patients with CF. In both lymphocytes (this study, 13) and granulocytes (22) only a small fraction of the beta adrenergic receptors need be occupied for full activation of adenylate cyclase to occur. If receptor number alone were reduced, maximal activation of adenylate cyclase and normal maximal levels of cAMP production should still be achieved, albeit at higher agonist concentration. This is not the case: in CF, maximal cAMP accumulation is reduced in both cell types (Figs. 1 and 3; references 1 and 4). Since adenylate cyclase itself is capable of achieving higher levels of cAMP production with other stimuli (Figs. 2, 4), in order to explain these findings, it is necessary to postulate impaired receptor-cyclase coupling or selective loss of a critical, active subpopulation of receptors.

The coupling of the beta adrenergic receptor to adenylate cyclase is complex. Required for coupling to occur is a protein or protein complex $\left(\mathrm{N}_{\mathrm{s}}\right)$ that binds guanine nucleotides, increasing adenylate cyclase activity and hormone response and decreasing the affinity of the beta adrenergic receptor for agonists but not antagonists (23). Several lines of evidence suggest that $\mathrm{N}_{\mathrm{s}}$ is not the cause of defective coupling in CF. Adenylate cyclase activity increases $(2)$ and the $K_{i}$ for 
isoproterenol at the beta adrenergic receptor decreases in the presence of GppNHp (Tables I, II) in CF lymphocyte and granulocyte particulates, suggesting the presence of functional $\mathrm{N}_{\mathrm{s}}$. In addition, a human disease apparently associated with reduced amounts of this coupling protein, pseudohypoparathyroidism type I, does not resemble CF (24). Nevertheless, more definitive experiments must be performed to establish whether this protein is abnormal in CF.

Abnormal receptor-cyclase coupling may be accompanied by derangement of agonist but not antagonist binding to the beta adrenergic receptor (25). However, this was not the case in the present study (Tables I and II). This may reflect insensitivity of our assay system to such changes or a possible effect of guanine nucleotides retained in the particulate preparations. Alternatively, it may indicate that another membrane component required for coupling is defective in CF. Additional studies will be required to resolve these questions.

\section{ACKNOWLEDGMENTS}

This work was supported by grants from the Cystic Fibrosis Foundation (I 007), the National Institutes of Health (HL28386 and AM 27651), and the Veterans Administration and by a Basil O'Connor Starter Research Grant (5-315) from the March of Dimes Birth Defects Foundation.

\section{REFERENCES}

1. Davis, P. B., M. Braunstein, and C. Jay. 1978. Decreased adenosine $3^{\prime}: 5^{\prime}$ cyclic monophosphate response to isoproterenol in cystic fibrosis leukocytes. Pediatr. Res. 12: 703-707

2. Davis, P. B., and S. C. H. Laundon. 1980. Adenylate cyclase activity in leukocytes from patients with cystic fibrosis. J. Lab. Clin. Med. 96: 75-85.

3. Davis, P. B., J. H. Shelhamer, and M. Kaliner. 1980. Abnormal adrenergic and cholinergic sensitivity in cystic fibrosis. N. Engl. J. Med. 302: 1453-1456.

4. Galant, S. P., L. Norton, J. Herbst, and C. Wood. 1981. Impaired beta adrenergic receptor binding and function in cystic fibrosis neutrophils. J. Clin. Invest. 68: 253258.

5. Lemanske, R. F., E. H. Mischler, P. M. Farrell, C. Anderson, and W. W. Busse. 1981. Analysis of granulocyte beta-adrenergic response in cystic fibrosis: correlation of decreased responsiveness with disease severity. Am. Rev. Respir. Dis. 123: 622-626.

6. Davies, A. O., and R. J. Lefkowitz. 1980. Corticosteroidinduced differential regulation of beta-adrenergic receptors in circulating human polymorphonuclear leukocytes and mononuclear leukocytes. J. Clin. Endocrinol. Metab. 51: 599-603.

7. Gullner, H. G., J. R. Gill, F. C. Bartter, and M. S. Kafka. 1980. Inhibition of prostaglandin synthesis increases leukocyte beta-adrenergic receptors in man. Clin. Res. 28: 479a. (Abstr.)
8. Sano, Y., M. Begley, G. Watt, A. Bewtra, and R. Townley. 1981. Disease and sex difference in leukocyte betaadrenergic receptors. Am. Rev. Respir. Dis. 123: 55a. (Abstr.)

9. Doershuk, C. F., L. W. Matthews, A. S. Tucker, H. Nudelman, T. G. Eddy, M. Wise, and S. Spector. 1964. A five-year clinical evaluation of a therapeutic program for patients with cystic fibrosis. J. Pediatr. 65: 677-684.

10. Boyum, A. 1968. Isolation of mononuclear cells and granulocytes from human blood. Scand. J. Clin. Lab. Invest. 21 (Suppl. 97): 77-89.

11. Aarons, R. D., A. S. Nies, J. Gal, L. R. Hegstrand, and P. B. Molinoff. 1980. Elevation of $\beta$-adrenergic receptor density in human lymphocytes after propranolol administration. J. Clin. Invest. 65: 949-957.

12. Brown, B. L., J. D. M. Albano, R. P. Ekins, A. H. Sgherzi, and $W$. Tampion. 1971. A simple and sensitive saturation assay method for the measurement of adenosine $3^{\prime}: 5^{\prime}$ cyclic monophosphate. Biochem. J. 121: 561-562.

13. Williams, L. T., R. Snyderman, R. J. Lefkowitz. 1976. Identification of $\beta$-adrenergic receptors in human lymphocytes by $(-)\left[{ }^{3} \mathrm{H}\right] \mathrm{alprenolol}$ binding. J. Clin. Invest. 57: 149-155.

14. Scatchard, G. 1949. The attractions of proteins for small molecules and ions. Ann. N.Y. Acad. Sci. 51: 660-672.

15. Cheng, Y., and W. H. Prusoff. 1973. Relation between the inhibition constant $\left(K_{i}\right)$ and the concentrations of inhibitor which cause $50 \%$ inhibition $\left(I_{50}\right)$ of an enzymatic reaction. Biochem. Pharmacol. 22: 3099-3108.

16. Dixon, T. F., and M. Purdom. 1954. Serum 5'-nucleotidase. J. Clin. Pathol. 7: 341-343.

17. Arkesteijn, C. L. M. 1976. A kinetic method for serum 5 -nucleotidase using stabilized glutamate dehydrogenase. J. Clin. Chem. Clin. Biochem. 14: 155-158.

18. Bradford, M. 1976. A rapid and sensitive method for the quantitation of microgram quantities of protein utilizing the principle of protein dye binding. Anal. Biochem. 72: 248-254.

19. Fraser, J., J. Nadeau, D. Robertson, and A. J. J. Wood. 1981. Regulation of human leukocyte beta receptors by endogenous catecholamines. Relationship of leukocyte beta receptor density to the cardiac sensitivity to isoproterenol. J. Clin. Invest. 67: 1777-1784.

20. Lake, C. R., P. B. Davis, M. Ziegler, and I. J. Kopin. 1979. Electrolytes and norepinephrine levels in blood of patients with cystic fibrosis. Clin. Chim. Acta. 92: 141146.

21. Styrt, B., J. T. Noble, and M. S. Klempner. 1982. The role of lysosomes in neutrophil uptake of beta-adrenergic ligands. Clin. Res. 30: 166a. (Abstr.)

22. Galant, S. P., and S. Allred. 1981. Binding and functional characteristics of beta-adrenergic receptors in the intact neutrophil. J. Lab. Clin. Med. 98: 227-237.

23. Rodbell, M. 1980. The role of hormone receptors and GTP-regulatory protein in membrane transduction. $\mathrm{Na}$ ture (Lond.). 284: 17-22.

24. Farfel, Z., A. S. Brickman, H. R. Kaslow, V. M. Brothers, and H. R. Bourne. 1980. Defect of receptor-cyclase coupling protein in pseudohypoparathyroidism. N. Engl. J. Med. 303: 237-242.

25. Harden, T. F., Y. Su, and J. P. Perkins. 1979. Catecholamine-induced desensitization involves an uncoupling of beta-adrenergic receptors and adenylate cyclase. J. Cyclic Nucleotide Res. 5: 99-106. 